Тетяна Грабович,

кандиьат юриьичних наук

https://doi.org/10.32782/2020-38-08

УДК 341.01

\title{
Сутність міжнародно-правової відповідальності держави як політико-правової цінності
}

Немає відповідальності, немає (міжнародного) права.

А. Пеллет

Надійно закріплений основний принцип міжнародної відповідальності передбачає, що кожне міжнародно-протиправне діяння держави тягне за собою міжнародно-правову відповідальність. Ідея, що лежить в основі відповідальності, гарантує нормативність міжнародного права та відводить положенням про відповідальність держави одне із центральних місць у міжнародному праві. Водночас право міжнародної відповідальності потребує детального врегулювання задля вирішення багатьох теоретичних дискусій та практичних складнощів.

Інститут відповідальності з найдавніших часів і до наших днів є одним iз способів забезпечення порядку у міжнародних відносинах [1, с. 3]. Значення міжнародно-правової відповідальності держави, як відзначає П.М. Куріс, зумовлене тим, що цей інститут $€$ необхідним юридичним засобом забезпечення міжнародного права, більш того - найважливішим елементом його сутності, однією з його підвалин. Право взагалі немислиме без відповідальності за порушення його норм [2, с. 10].

П. Рейтер вважає, що відповідальність, знаходячись у серці міжнародного права, складає суттєву частину того, що можна назвати Конституцією міжнародного співтовариства [3, с. 3]. Заперечення принципу міжнародної відповідальності держави, на думку А. Фердросса, призвело б до загибелі міжнародного права, оскільки 3 відмовою від відповідальності за вчинене протиправне діяння відпали б також зобов'язання держав дотримуватися норм міжнародного права [4, с. 353].

В.А. Василенко справедливо відзначає, що існування внутрішньодержавних i міждержавних суспільних відносин було б неможливим, якби суб'єкти цих відносин не несли відповідальності за свою поведінку. Відповідальність необхідно притаманна суб'єктам будь-якої соціальної спільності. Саме вона забезпечує впорядкованість відносин, що складаються між ними в 
процесі їх спільної діяльності [5, с. 5]. Як стверджує Ю.М. Колосов, значення міжнародної відповідальності полягає в тому, що вона є принципом, що лежить в основі взаємного прагнення держав уникнути спричинення шкоди одна одній. Таке положення особливо важливе саме для міжнародних відносин, де, на відміну від внутрішньодержавних відносин, не існує спеціального апарату примусу, що забезпечував би невідворотність відповідальності та відшкодування шкоди [1, с. 21].

I.I. Лукашук, підкреслюючи виняткову роль відповідальності в міжнародному праві, звертає увагу на той факт, що у значному числі випадків порушення внутрішнього права залишаються або невідомими, або не вдається виявити тих, хто їх вчинив. У міжнародному праві подібне становище практично виключено, що й надає міжнародній відповідальності особливе значення [6, с. 1]. Відповідальність є обов'язковим, неминучим наслідком права, про що зазначалося Міжнародним судом ООН у відомому рішенні Barcelona Traction, Light and Power Company [7, c. 3].

Різноманітним аспектам міжнародно-правової відповідальності держав присвячені праці у вітчизняній та зарубіжній міжнародно-правовій літературі. Серед авторів, які висвітлюють дану проблематику, слід назвати таких вчених, як А. Абасс, Р. Аго, С.Ф. Амерасінг, В.Ф. Антипенко, Е. Аречага, P.P. Батршин, Я. Броунлі, О.В. Буткевич, К.А. Важна, В.А. Василенко, Л.Г. Гусейнов огли, В.Н. Денисов, Д. Джінкс, О.В. Задорожній, А. Зайберт-Фор, І. Зіємель, І.І. Лукашук, Ю.М. Колосов, Б. Конфорті, Дж. Кроуфорд, П.М. Куріс, В.А. Мазов, С. Оллесон, М. Сассолі, Г.І. Тункін, М.О. Ушаков, Ж.-М. Хенкертс, М.Х. Фарукшин та ін.

Метою статті є висвітлення сутності міжнародно-правової відповідальності держави як політико-правової цінності на підставі аналізу доктринальних джерел та практики міжнародних органів.

Відповідальність держави є основоположним принципом міжнародного права, що випливає із природи міжнародної правової системи і доктрин державного суверенітету і рівності держав [8, с. 694]. На взаємозв'язок відповідальності та суверенітету вказує А. Пеллет, на думку якого відповідальність взаємодіє 3 поняттям суверенітету і впливає на його визначення, у той же час повсюдність суверенітету у міжнародних відносинах неминуче впливає на концепцію міжнародної відповідальності. Разом із тим відповідальність глибоко еволюціонувала разом із самим міжнародним правом: відповідальність є наслідком міжнародного права, найкращим доказом його існування та найбільш вірогідним показником його ефективності [3, с. 3].

Із цього приводу Р. Аго у своїй доповіді перед Комісією міжнародного права ООН (далі - КМП ООН, Комісія) справедливо відзначав, що спроби, як це робили в минулому деякі прихильники державного абсолютизму, заперечити ідею відповідальності держави, оскільки вона нібито суперечить ідеї суверенітету, означають заперечення існування міжнародно-правового порядку [9, п. 31].

Варто відзначити, що в юридичній літературі вже майже не зустрічається концепцій, що протиставляють суверенітет і міжнародно-правову відповідальність держави, а окремі рецидиви ідей німецької історичної школи права, яка оскаржувала саме можливість взаємної відповідальності держав, залишилися в минулому [2, с. 28]. Відповідальність не тільки не суперечить суверенітету, а й зумовлена ним, якщо розуміти суверенітет як необхідну передумову гармонійного співробітництва в руслі суверенної рівності, а не як підставу для зазіхань на особливі права сильних світу цього. 
На підставі суверенітету держави створюють міжнародне право, наділяють його юридичною силою 3 тим, аби 3 його допомогою забезпечувати свої суверенні права. Навіть у внутрішній сфері суверенітет не означає свободи держави від встановлених законів. Зростає значення міжнародного права i у визначенні характеру взаємодії внутрішнього та зовнішнього аспекту суверенітету держав. Міжнародне право закріплює свободу держави визначати свій внутрішній правопорядок з урахуванням своїх міжнародних зобов'язань. Сучасне загальне міжнародне право висуває певні вимоги до внутрішнього правопорядку, головним чином, щодо основних прав і свобод людини. Такий правопорядок має будуватися таким чином, щоб забезпечити виконання державою приписів міжнародного права, в іншому випадку виникає іiі міжнародно-правова відповідальність [6, с. 20]. Тому суверенітет держави та ii незалежність у зовнішніх зносинах не може надавати необмежену свободу дій у міжнародному спілкуванні, цілковиту незалежність від інших держав світу та абсолютну ізоляцію на міжнародній арені.

Термін «міжнародна відповідальність» охоплює нові правовідносини, що виникають за міжнародним правом внаслідок міжнародно-протиправного діяння держави. Таке трактування КМП ООН.

Варто відзначити наявність $\mathrm{y}$ юридичній літературі різних точок зору щодо визначення правовідносин, які виникають у результаті міжнародно-протиправного діяння. Можна виділити три основні позиції із цього питання. Згідно 3 першою, прихильником якої був Анцилотті, юридичні результати міжнародно-протиправного діяння описуються виходячи 3 того, що такі результати мають зобов'язальну силу двосторонніх відносин, які виникають між державою-порушницею та потерпілою державою, в межах яких зобов’язання першої держави забезпечити відшкодування співвідноситься із суб'єктивним правом іншої держави вимагати відшкодування. Прихильники іншої точки зору, що підтримувалася Кельзеном, виходять із того, що правопорядок є примусовим порядком, та розглядають дозвіл, що наданий потерпілій державі застосовувати примусові санкції проти держави, що несе відповідальність, в якості первинного юридичного наслідку, що безпосередньо витікає із протиправного діяння. Згідно із третім підходом, що став найбільш визнаним, наслідки міжнародно-протиправних діянь не можуть обмежуватися відшкодуванням або «санкціями» [10, с. 33].

КМП ООН визначила відповідальність держав як «усі види нових правовідносин, які можуть виникнути в рамках міжнародного права в результаті міжнародно-протиправного діяння держави незалежно від того, чи обмежуються такі відносини правовідносинами між державою, що вчинила протиправне діяння, і державою, яка безпосередньо постраждала, або ж вони поширюються також на інших суб'єктів міжнародного права, i незалежно від того, чи сконцентровані вони на зобов'язанні винуватої держави відновити у правах державу, яка постраждала, і стягнути заподіяні їй збитки (шкоду), або охоплюють також право самої держави, яка постраждала, або інших суб'єктів міжнародного права застосувати до винуватої держави будь-яку санкцію, допустиму міжнародним правом» [11, с. 175].

Широко розповсюдженим $\epsilon$ визначення міжнародно-правової відповідальності як негативних юридичних наслідків, що наступають для суб'єкта міжнародного права в результаті порушення ним міжнародно-правового зобов'язання [12, с. 460$]$.

А. Пеллет справедливо наголошує на тому, що загалом розуміння відповідальності в міжнародному праві 
зазнало кардинальних змін у результаті еволюції, що відображає розвиток самого міжнародного права, адже, зокрема, відповідальність більше не зарезервована лише для держав і слугуе визнанням правосуб'єктності інших суб'єктів міжнародного права; вона втратила свою концептуальну єдність у результаті припинення визнання шкоди умовою для відповідальності за порушення [3, с. 6]. Міжнародне право повинно дотримуватися незалежно від наслідків порушення, і будь-яке порушення тягне за собою відповідальність його актора, тоді як зміст такої відповідальності, її конкретні наслідки варіюються залежно від того, чи спричинено шкоду таким міжнародно-протиправним діянням, і відповідно до характеру порушеної норми. Ця реконцептуалізація міжнародної відповідальності, описана як «революційна», свідчить про (відносний) прогрес солідарності в міжнародному суспільстві. Слід також брати до уваги, що транскордонне співробітництво завдяки науково-технічному прогресу, що може завдати тяжкої шкоди індивідам та навколишньому середовищу, як у міжнародно-правовому порядку, так і у вітчизняних правових системах, спричинило необхідність розгляду питання про те, чи повинна існувати сувора відповідальність «strict liability» [3, с. 9].

Загалом, розвиток поняття та сутності міжнародної відповідальності держави нерозривно пов'язаний із роботою КМП ООН. Ще 1949 р. Генеральна Асамблея ООН визнала тему відповідальності держави як одну із обов'язкових для обговорення КМП $\mathrm{OOH}$, і ця тема залишалася частиною роботи Комісії до 2001 р., коли було прийнято Статті про відповідальність держав за міжнародно-протиправні діяння. Водночас робота 3 питання міжнародної відповідальності держави не припиняється і сьогодні.

До прикладу, в резолюції А/74/421 від 18 грудня 2019 р. [13]
Генеральна Асамблея ООН відмітила, що тема відповідальності держав за міжнародно-протиправні діяння має величезне значення у відносинах між державами, продовжує визнавати важливість та корисність Статей про відповідальність держав за міжнародно-протиправні діяння та знову постановила включити в проект порядку денного своєї сімдесят сьомої сесії пункт, що має назву «Відповідальність держав за міжнародно-протиправні діяння», і продовжити в рамках робочої групи Шостого комітету з метою прийняття рішення розгляд питання про конвенцію про відповідальність держав за міжнародно-протиправні діяння чи інших належних заходи на основі статей.

Про авторитет Статей про відповідальність держав за міжнародно-протиправні діяння свідчать постійні посилання на цей документ у рішеннях різних міжнародних судових установ [14]: Міжнародного Суду ООН; Міжнародного трибуналу з морського права; Міжнародного кримінального суду; груп Всесвітньої організації торгівлі; міжнародних арбітражних трибуналів; Африканського суду 3 прав людини і народів; Африканської комісії з прав людини і народів; Свропейського суду з прав людини; Міжамериканського суду з прав людини; Карибського суду; Суду Економічного співтовариства західноафриканських держав; Спільного суду Свропейського союзу.

Так, зокрема, у справі Quiborax S. A., Non Metallic Minerals S. A. and Allan Fosk Kaplún v. Plurinational State of Bolivia (2015) Міжнародний арбітраж (за Конвенцією МЦВIC) зазначив, що закріплений у статті 1 принцип, згідно 3 яким держава несе відповідальність за свої міжнародно-протиправні діяння, $є$ «одним із базових принципів міжнародного права» [15, п. 327]. В іншій справі Suez, Sociedad General de Aguas de Barcelona S. A. and Vivendi 
Universal S. A. v. The Argentine Republic (2015) арбітражний трибунал наголосив на тому, що «термін «міжнародна відповідальність» ... охоплюе нові правові відносини, що виникають згідно 3 міжнародним правом у зв'язку з учиненням державою міжнародно-протиправного діяння» [16, п. 25].

Одним із принципів, коріння якого глибоко вкорінені в доктрині міжнародного права і підтверджуються практикою держав та міжнародними судовими рішеннями, є принцип, згідно з яким будь-яка поведінка держави, що є міжнародно-протиправною, тягне за собою міжнародно-правову відповідальність такої держави.

Труднощі в досягненні консенсусу щодо основних аспектів міжнародно-правової відповідальності держави та різноманіття думок у КМП ООН під час розроблення кодифікаційного акта свідчить про наявність багатьох суттєвих невизначеностей, що характерні для цієї сфери міжнародного права. Зокрема, дискусії викликають такі питання, як розмежування міжнародно-правової відповідальності держави та індивіда; питання вини держави; об'єктивної відповідальності держави; особливості застосування обставин, що виключають протиправність діяння держави; кваліфікації діяння як міжнародно-протиправного тощо. Тому проблеми міжнародно-правової відповідальності держави продовжують активно обговорюватися на міжнародному рівні й потребують свого подальшого грунтовного вивчення.

\section{Список використаних джерел}

1. Колосов Ю.М. Ответственность в международном праве. Москва : Юридическая литература, 1975. 255 с.

2. Курис П.М. Международные правонарушения и ответственность государства. Вильнюс, 1973. 279 c.

3. Pellet A. The definition of responsibility in International law. Chapter 1. In J. Crawford, A. Pellet, S. Ollesson (eds). The Law of International Responsibility. 2010. P. 3-16.

4. Международное право. Перевод с немецкого. Фердросс А.; под ред.: Тункин Г.И. (Предисл.). Москва : Иностр. лит., 1959. 652 с.

5. Василенко В.А. Ответственность государства за международные правонарушения. Киев : Вища школа, 1976. 267 с.

6. Лукашук И.И. Право международной ответственности. Москва : Волтерс Клувер, 2004. 432 c.

7. Barcelona Traction, Light and Power Company, Limited (Belgium v. Spain) Judgment of 5 February 1970. ICJ Reports. 1970. P. 3.

8. Shaw Malcolm N. International Law. 5th Edition. Cambridge: Cambridge University Press, 2003. 1288 p.

9. Ago R. Third Report on State Responsibility. Yearbook of the International Law Commission. 1971. Vol 11 (1).

10. Commentaries to the draft articles on Responsibility of States for internationally wrongful acts adopted by the International Law Commission at its fifty-third session. Yearbook of the International Law Commission. 2001. Vol. II, Part Two.

11. Yearbook of the International Law Commission. 1973. Vol. II.

12. Див.: Буткевич В. Г. Міжнародне право. Основи теорії : підручник / В.Г. Буткевич, В.В. Мицик, О.В. Задорожній. Київ : Либідь, 2002. 608 с.

13. United Nations. General Assembly. Seventy-fourth session. Resolution 74/180. 18 December 2019 Responsibility of States for internationally wrongful acts. UN Doc. A/RES/74/180. URL: https://undocs.org/en/A/RES/74/180.

14. Див. Seventy-fourth session. Responsibility of States for internationally wrongful acts Responsibility of States for internationally wrongful acts. Compilation of decisions of 
international courts, tribunals and other bodies Report of the Secretary-General. UN Doc A/74/83.

15. ICSID. Quiborax S.A., Non Metallic Minerals S.A. and Allan Fosk Kaplún v. Plurinational State of Bolivia. Case No. ARB/06/2. Award. 16 September 2015.

16. ICSID. Suez, Sociedad General de Aguas de Barcelona S. A. and Vivendi Universal S. A. v. The Argentine Republic. Case No. ARB/03/19. Award. 9 April 2015.

Грабович Т. А. Сутність міжнародно-правової відповідальності держави як політико-правової цінності

Стаття присвячена висвітленню сутності міжнародно-правової відповідальності держави як політико-правової цінності на підставі аналізу доктринальних джерел та практики міжнародних органів. Визначено, що ідея, що лежить в основі міжнародно-правової відповідальності, гарантує нормативність міжнародного права та відводить положенням про відповідальність держави одне із центральних місць у міжнародному праві. Обгрунтовано, що суверенітет держави та її незалежність у зовнішніх зносинах не може надавати необмежену свободу дій у міжнародному спілкуванні, цілковиту незалежність від інших держав світу та абсолютну ізоляцію на міжнародній арені. Наведено різні позиції щодо визначення правовідносин, які виникають у результаті міжнародно-протиправного діяння. Встановлено, що наслідки міжнародно-протиправних діянь не можуть обмежуватися відшкодуванням або «санкціями»; що правовідносини, які виникають у результаті міжнародно-протиправного діяння, не обмежуються відносинами між державою, що вчинила протиправне діяння, і державою, яка безпосередньо постраждала, а поширюються також на інших суб'єктів міжнародного права. Визначено, що розуміння міжнародної відповідальності держави зазнало кардинальних змін у результаті еволюції самого міжнародного права. Окреслено роль КМП ООН у виробленні норм про міжнародно-правову відповідальність держав та значення Статей про відповідальність держав за міжнародно-протиправні діяння 2001 р. для практики держав та міжнародної судової практики, зокрема для Міжнародного Суду ООН; Міжнародного трибуналу з морського права; міжнародних арбітражних трибуналів тощо. Встановлено, що труднощі в досягненні консенсусу щодо основних аспектів міжнародної відповідальності держав свідчить про наявність багатьох суттєвих невизначеностей, що характерні для цієї сфери міжнародного права та потребують свого подальшого грунтовного вивчення.

Ключові слова: сутність міжнародно-правової відповідальності, міжнародно-правова відповідальність держави, Комісія міжнародного права ООН, Статті про відповідальність держав за міжнародно-протиправні діяння.

\section{Hrabovych T. The essence of international responsibility of state as a political and legal value}

The article is devoted to the essence of international responsibility as a political and legal value based on the analysis of doctrinal sources and practice of international bodies. It is determined that the idea underlying international responsibility guarantees the normativity of international law and one of the central places in international law to the provisions on state responsibility. It has been substantiated that the sovereignty of the state and its independence in external relations cannot provide unlimited freedom of conduct in international communication or complete independence from other states and absolute isolation in the international arena. Various positions on the definition of legal relationship which arises upon the commission by a State of an internationally wrongful act are presented. It has been established that the consequences of internationally wrongful acts cannot be limited either to reparation or sanctions; legal relationship arising as a result of an internationally wrongful act is not limited to the relationship between the state that committed the wrongful act and the state directly affected, but also extend to other subjects of international law. It was determined that the understanding of international responsibility has undergone a change as 
a result of the evolution of international law itself. The role of the ILC in the development of rules on international responsibility of states and the importance of the Articles on the responsibility of states for internationally wrongful acts for the practice are determined. It was found that the difficulties in reaching a consensus on the main aspects of the international responsibility of states indicate the presence of many significant uncertainties of this area of international law and require further careful study.

Key words: essence of international responsibility, international responsibility of state, International Law Commission, Articles on Responsibility of States for internationally wrongful acts. 